\title{
The developement of personal skills by collaborative learning activities
}

Constantina Catalano 


\title{
The developement of personal skills by collaborative learning activities
}

\author{
Constantina Catalano ${ }^{\mathrm{a}^{*}}$ \\ ${ }^{a}$ Faculty of Psychology and Educational Sciences, Babeş-Bolyai University, 7 Sindicatelor Street, 400015, Cluj-Napoca, Romania \\ *Corresponding author: constantina.catalano@ubbcluj.ro
}

Abstract

Keywords:

soft skills, collaborative learning, teamwork abilites
The aim of our study is to highlight the potential of using the blended-learning, flipped classroom, learning strategies in developing the students' competences in the subject of Visual Arts and Practical Abilities within the framework of European school partnerships. The practical and process-oriented research will investigate and describe the gains of flipped classroom strategy in improving the artistic-plastic performances of young students aged 7-9 years, participants in the eTwinning Programme. By means of comparative analyses, we will bring out the effects of applying this strategy to students from Romania, Poland, Turkey and the Republic of Moldavia with regard to forming and developing their visual art competences. We framed these specific competences present in the 4 European countries'curriculum into the plastic theme category, with the subcategories of observing the artistic movement, selected technique, type of chosen tools and materials, lines diversity and expressivity, diversity and complexity of shapes, chromatic harmony, colour surface, ornamentation of composition.

\section{Zusammenfasung}

Schlüsselworte:

Soft-Skills, Kollaboratives Lernen, Teamwork Fähigkeiten
Die Zusagen für die Zusammenarbeit sind in akademischen Lerngemeinschaften sehr üblich. Daher betonen wir in diesem Artikel die Tatsache, dass das Vorhandensein der Soft Skills die Qualität der den Schülern erteilten Leistungen verbessert. Persönliche und soziale Kompetenzen wie "Soft Skills" beziehen sich auf persönliche Attribute, die die Interaktion mit den einzelnen Personen, die Arbeitsleistung und die Karrierechancen verbessern. Persönliche Fähigkeiten werden oft mit Persönlichkeitsmerkmalen wie Optimismus, Verantwortung, Integrität, Humor, Unterscheidungsvermögen, Weisheit, Klugheit, gesundem Menschenverstand usw. in Verbindung gebracht. Einige persönliche Attribute können durch Übung und Praxis verbessert werden: gutes Benehmen Fuhrungund Teamgeist, Verhandeln oder Geselligkeit. Die Generierung und Aufrechterhaltung kollaborativer Aufgaben im akademischen Umfeld umfasst eine Vielzahl von Anliegen und spezifischen Ansätzen, die auf verschiedene Weise behandelt werden können.

\section{Introduction}

Current policies of education, such as the constructivist model of training or interactive pedagogy, increasingly raise the concern of electing active strategies for including collaborative learning in current school, practice at all levels of education, from pre-school to university.

Education in Romania still kept, sometimes, excessive intransigence specific for competitive environments. It is not claimed that being competitive, as a personality attribute, would have a negative connotation, but it is considered that school environments that continuously rely on student or student competition will fail to form or consolidate many of the specific features or teamwork, that is so necessary for any field of work.

Personal skills and social skills such as "soft skills" have been increasingly highlighted in modeling skills in any field of activity. In the first instance, the term "soft" is opposed to "hard", by "hard skills" understanding the technical skills, namely computer operation, calculus, language knowledge etc.

The soft skills phrase has benefited from several other substitutes, including: "life, social and personal skills", "transferable skills", "life skills" etc. Of these, the closest to the profound meaning of what these skills imply would be their quality to be socially and personally useful, therefore transferable.

We define personal and social skills as intra and interpersonal (socio-emotional) characteristics, essential for personal development, social participation and success in the field of activity. The most often mentioned are: communication skills, ability to work in team or adaptability. Regarding the special attributes that any person should have in general, in addition to the formal 
competences indicated, at the level of professional, technical, ethical, etc., we should identify them in the area of transferable competences and personal and social characteristics, those which are indeed of great importance in the selection of future teachers. This set of features is, in fact, the superior ability to apply existing skills under the conditions of a possible change and can be grouped into the following categories: analytical, communication, interpersonal, organizational, problem-solving etc.

Social skills such as "soft skills" refer to personal attributes that enhance individual interactions, workplace performance, and career prospects. Unlike technical abilities, which relate to the set of specific capacities of a particular field of work (for example, the professional technical skills of a surgeon, architect or dentist) that a person has, social skills and personal data are transferable and have very wide applicability.

Personal skills are often associated with personality traits such as: optimism, responsibility, integrity, sense of humor, discernment, wisdom, prudence, good sense, etc., but also with other personal attributes that can be improved through exercise and practice: empathy, team spirit, leadership, communication, assertiveness, good manners, negotiation, sociability or the ability to learn.

In the academic environment, especially in the faculties that form future teachers, the proposal to work and learn collaboratively should become a frequent practice. Teamwork and collaborative learning become imperative for the training of the teaching staff at present.

\section{Collaborative learning approaches and} implications of personal skills in the process

Collaborative learning is an educational approach to teaching and learning that involves groups of students working together to solve a problem, complete a task, or create a product (Gerlach, 1994, apud McLaren, 2014). Collaborative learning is defined generally as the form of group learning in which there are significant interactions between students.

Collaboration also supports stimulating students and enhancing their performance, as it offers them the opportunity to make their own contribution when it comes to the task being done. Exploiting the contributions of each member of the group may lead to the emergence of ideas that group members did not have before, in other words, one group comes up with an idea and departs from the collective discussion with several, taken from other members of the group.

Collaborative learning can also be a didactic strategy that aims to raise cognitive and social interdependence among participants by taking into account inter-individual differences and investing educational agents with an active role. This articulates the individual approaches of each student with those of the membership group. Knowing each other better, students have no restraint in asserting their own knowledge. They learn to listen to the views of those in the group, even if they are different from their own, to support their knowledge by arguing them, engaging in critical and creative thinking, and openly engaging in dialogue.

The essential components of a collaborative learning activity in groups of students are (Nicu \& Conţiu, 2010, p. 42):

\section{Grouping of students}

2. Face-to-face interaction

3. Positive interdependence

4. Individual responsibility

5. Training and development of cognitive and cooperative skills

6 . The role of the teacher

7. Social interactions

1. Grouping the students usually remains the task of the teacher or coordinator of the collaborative learning activity. There are two central milestones in the grouping of learners: roles and tasks. Also, the major coordinates in creating cooperative learning situations are: motivation, communication and mutual acceptance.

2. Face-to-face interaction requires effective contact with group colleagues. Students or students work together, promoting everyone's successes, sharing resources, helping, supporting and encouraging each other's efforts.

In this process of face-to-face interaction, cognitive processes and elements of interpersonal dynamics arise, which activate when those involved support each other in the learning process. This translates into practices such as: oral explanation of how to solve a problem, teaching knowledge in pairs, providing feed-back, recapping knowledge and making connections between old and new knowledge. 
3. Positive interdependence occurs when group members work together to achieve the intended goal by participating equally and actively in the task, sharing their knowledge, experiences and resources.

Knowing that the task assigned to them cannot be done individually, they are aware that they need the others to succeed. The solid structure of positive interdependence leads learners to realize that the success of the group depends on the effort made by all members to carry out the task, each contributing their own contribution, making a joint effort to fulfill its role and responsibilities.

4. Individual responsibility (roles and tasks) refers to the fact that each member of the group assumes responsibility for the task to be solved by helping the other members of the group to learn. Each group is responsible for the achievement of the set goal and each member is responsible for his or her personal contribution to achieving the goal of each individual's acquisition.

5. Training and development of cognitive and cooperative skills is necessary for cooperative situations. Groups cannot exist and cannot function unless students have and do not use certain cognitive and social skills that are essential to the functioning and achievement of the goals of cooperation.

6. The role of the teacher is described on two main coordinates (Clarke, 1992, apud Nicu \& Conțiu, 2010): observation of working groups and support. As role assigned to the teacher, it is recommended: the role of planning, the role of observation, the role of intervention and the role of reflection (Howden, 1997, apud Nicu \& Conţiu, 2010).

7. Social interactions capture the efficiency of learning in a collaborative context, demonstrated by the innumerable results of the research that goes in this direction, especially those related to the constructivist approaches of cooperative learning.

Therefore, it is visible that real contribution in collaborative tasks given to students involves their active participation in them, and by interacting with colleagues, these personal and social skills will develop.

The soft skills needed for collaboration: respect for others, acceptance of differences, political expression of disagreement, description of feelings, manifestation of preoccupation with others, etc. Among the cognitive abilities proposed by him are the following: evaluation of ideas, analysis, justification of opinions, comparison and opposition, the question of deepening the meaning, proposing solutions for change, the integration of ideas, etc. (Abrami, Poulsen \& Chambers, 2004).

Social skills can also be shared in this way: tasks related to assignment (questioning, requesting clarification, checking the understanding, tracking of notes etc.) and skills related to working realities (encouraging, recognizing contributions, affective participation, maintaining calm etc.).

All of these group skills are learned, they are not instinctive, so the teacher's task is to ensure that they assign precise roles to each student or student within the team to perform the proposed collaboration or cooperation.

The essential features that we will continue to address are represented in the area of collaboration and cooperation, areas involving a wide range of specific abilities, such as: line waiting, information communication, helping, reformulating, summarizing ideas out loud, criticizing and also team spirit, empathy, adaptability, or willingness to engage in collective tasks.

Interactivity, interpersonal, problem-solving, and communication skills are needed for a group engaged in a common task that has complementary roles, pursues the same goal, accomplish a task that has to be performed far beyond what he would do it individually.

We enumerate the important features that we identify at the personal level, the students who are to be involved in collaborative tasks, to maintain a working group (Crebert et al., 2011):

- Ability to communicate effectively orally with others;

- Ability to communicate effectively in writing with others;

- Ability to communicate effectively with ICT, multimedia etc. with others;

- Ability to interact and collaborate with others effectively, including in teams, at work or in various cultural or linguistic contexts.

Moreover, we believe it deserves to be reminded of another feature that helps, through its presence in the construction of a study group or an efficient working team, namely flexibility. This quality refers to the adaptability to 
the group itself, to its members, to the profile of the work tasks or to their volume, to the changes that may occur in its dynamics etc.

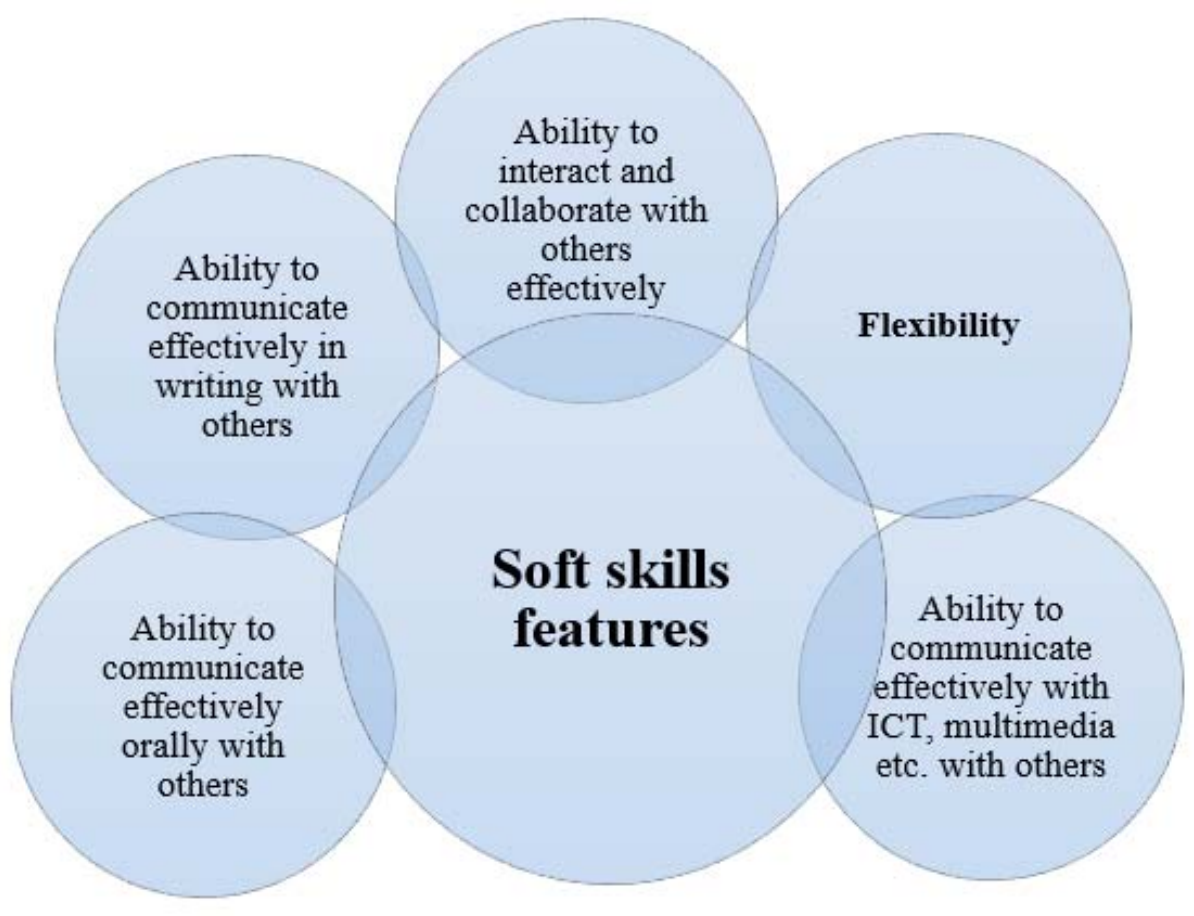

Figure no. 1. The dynamic of the soft skills features

The above features may be operationalized at the level of the qualitative analysis of the performance and presence of the students in a work team or in a study group.

Also, we want to emphasize some argumentative circumstances that support collaborative learning activities to strengthen transversal transfer skills over the long term (Laister \& Kober, 2002):

A. Daily practice: In day-to-day collaboration, collaboration typically occurs in projects involving student groups or students who engage in cooperative activities to solve a problem or write research papers with colleagues. Contextual contexts in which collaborative learning must be encouraged or guided, but sometimes also as a result in everyday activities are identified. (Dillenbourg, 1999).

B. Organizational Context: Collaboration is a common practice for achieving objectives by bringing together experts, multidisciplinary teams, etc. The challenge in these formulas is to motivate each member to contribute with his expertise in order to achieve a commitment to learning and working together. Once the person is accustomed to engaging in collaborative activities in the student or student life environment, in the long run, as an employee, he / she will have the ability to make faster decisions within the organization. We can therefore say that training in such tasks prepares the ground for later, at work, for working with colleagues, managers etc.

C. Empirical Research: Research shows that collaborative learning compared to individual or competitive learning brings students to a higher level of achievement, i. e their problem-solving skills (acquired in the collaborative register), gives them cognitive advantages, which (Tozer, 1995, Webb, 1984, Bargh \& Schul, 1980 apud. Laister \& Kober 2002) have positive influences in consolidating the personality traits, beneficial to the future learning, whether autonomous or cooperative, and engaging in related work tasks.

As a consequence of all these theoretical researches that we studied, in order to encourage collaborative activities and the soft skills development, for a few years now, the themes we propose for the student seminars are designed to be prepared in working groups. The involvement of students in solving the projects and works given for the seminars was impressive. If in the first year of study we had to propose collaborative learning 
activities, in the 2nd year of study, those who were already familiar with our work style, this idea came from the students themselves, and they propose to work in the groups. They were very enthusiastic about this approach and made out projects and papers of great value, didactically and scientifically.

\section{Conclusions}

As a conclusion of all aspects presented, we argue that the foundation of a modern, high quality education cannot be produced in the absence of collaboration at all levels, either at the micro group level or at macro level education, or globally, of everything that means education in the world.

Therefore, university teachers should systematically train students to develop and strengthen transferable personal and social skills such as soft skills by proposing specific activities and tasks that aim at collaborative learning.

Soft skills can be developed by interacting with others. These must always be practiced being redeemed, so an easy opportunity to help students for improving their skills is to generate cooperative learning tasks for seminar activities. This is why we assume the fact that in any learning community it is mandatory to challenge the students for working together to accomplish their tasks: papers, projects etc.

It is said that technical skills will make you win an interview for employment and getting a job, but then personal skills are required to keep it.

\section{Authors note:}

Constantina Catalano is an Assistant Professor in the Department of Educational Sciences, Faculty of Psychology and Educational Sciences, Babeş-Bolyai
University, Ph.D. in Educational Sciences. Her research is in the field of academic learning, focused on collaborative learning strategies, CSCL, alternative education.

\section{References}

Abrami, P. C., Poulsen, C., Chambers, B. (2004). Teacher motivation to implement an educational innovation: factors differentiating users and non-users of cooperative learning. Educational Psychology, 24:2, 201-216. http://doe.concordia.ca/cslp/cslp_cms/sites/all/themes/jfra me/downloads/PDF/Abrami_EP04.pdf.

Clarke, J., Wideman R. et Eadie, S. (1992). Apprenons ensemble: l'apprentissage coopérative en groupes restreints. Montréal: Les Éditions de la Chenelière.

Crebert, G., Patrick, C.J., Cragnolini, V., Smith, C., Worsfold, K., \& Webb, F. (2011). Griffith Graduate Attributes Teamwork Skills Toolkit. http://www.griffith.edu.au/_data/assets/pdf_file/0008/29 0870/Teamwork-skills.pdf.

Dillenbourg, P. (1999). What do you mean by "collaborative learning"? In P. Dillenbourg (Ed.), Collaborative learning: Cognitive and computational approaches, Amsterdam, NL: Pergamon, Elsevier Science.

Gerlach, J. M. (1994). Is this collaboration? In Bosworth, K. and Hamilton, S.J. (Eds.), Collaborative learning: Underlying processes and effective techniques. New directions for teaching and learning, No. 59.

Laister, J., Kober, S. (2002). Social Aspect of Collaborative Learning in Virtual Environments. http://www.networkedlearningconference.org.uk/past/nlc 2002/proceedings/papers/19.htm.

McLaren, B. (2014). What happens when we learn together. https://www.cs.cmu.edu/ bmclaren/pubs/WileyColaborativeLearningWhitePaper-2014.pdf.

Nicu, A., Conțiu, E.R. (2010). Instrumente pentru învățarea prin cooperare, Aramis, București.

Tozer, S.E., Violas, P.C., Senese, G.B. (1995). School and Society. Historical and Contemporary Perspectives. New York: McGraw-Hill. 